\title{
The Influence of God Consciousness and Religiosity in Coping with Anxiety at Workplace among Malaysian Muslim Professionals
}

\author{
Husni Mohd Radzi, Lilie Zahara Ramly, Sapora Sipon, and Khatijah Othman
}

\begin{abstract}
Anxiety is form of psychological condition that can cause serious harm to human mind and overall well being. Today's stressful and highly demanding work setting has intensified the pressure and expectations felt by the professionals in Malaysia. The intensity of stress may affect general safety, health and even lifestyles or relationships of a normally working persons. There are some people who turn to God and religion as alternative to heal or cope with their psychological discomfort. Thus, this study was conducted to discuss the level of anxiety and other psychological discomforts experienced by group of Muslim working people in several sectors and examined how God consciousness and religiosity could influence as a mechanism to control their anxiety. The data was collected through random sampling of 38 working citizens of Malaysia from several working sectors. This study utilised two main instruments to measure the outcome: first, 'Depression, Anxiety and Stress scale' or 'DASS' to gauge the level of anxiety and 'Brief Religious Coping' (BRCOPE) to investigate religious coping performed by respondents in dealing with their anxiety.
\end{abstract}

Index Terms-Anxiety, stress, religious act, God consciousness.

\section{INTRODUCTION}

Anxiety and fear are basic human emotions that can be seen as normal internal or external reactions in dealing with stressor that were deemed crucial for survival of the species [1]. Anxiety can be explained as the feeling of lack of control related to future of things that are uncertain, which may lead to negative results [2]. According to Diagnostic and Statistical Manual of Mental Illness (DSM IV), anxiety is a feeling that is illogical but the person who experienced it felt unable to control their worries [3]. When the feelings of illogical fear become so overwhelmed, it may escalate which leads to anxiety disorder [4]

In Islamic point of view, anxiety is considered as spiritual disease which develops from unhealthy spiritual beliefs deep-rooted in the human heart [5]. Al-Ghazali, a prominent Islamic figure in spiritual field has characterized anxiety as

Manuscript received July 15, 2013; revised October 5, 2013. This work was supported in part by the Ministry of Higher Education of Malaysia under Grant LRGS USIM/LRGS (UUM)/FKP/ULUM/34/50112. The Influence of God Consciousness and Religiosity in coping with Anxiety at Workplace among Malaysian Muslim Professionals.

Husni Mohd Radzi, Sapora Sipon, and Khatijah Othman are with the Faculties of Leadership and management, Universiti Sains Islam Malaysia, Bandar Baru Nilai, 71700, Negeri Sembilan (e-mail: husnimr@gmail.com, sapora@usim.edu.my, khatijahothman@usim.edu.my).

Lilie Zahara Ramly is with the Universiti Tenaga Nasional, KM 7 Jalan Ikram-UNITEN, 43000, Kajang, Selangor (e-mail: lilie@uniten.edu.my). 'fear towards certain things which leads to restlessness and frustrated feelings' [6]. Fear towards inevitable environmental factors such as old age, poverty, losing status quo and job can sometimes lead a person to experience breakdown and lose their self-esteem. The pressure of dealing with life issues such as divorce, death of loved ones, health and financial problems can be very stressful that it eventually leads to anxiety [7]. It is common that many people cope with their anxiety by consumption of alcohol and other substances or recreational drugs which quickly lead them into severe problem which may have long term effects, such as addiction. The problem may then affect their functioning and relationship with family, friends and at the workplace.

The Islamic faith believes that anxiety is developed within a person's spiritual and psychological outlooks, which includes the weakness in asserting control through one's heart and mind, faith or believe system attached with the influence of worldly or narcissistic desires [8], [9]. Being in this state has opened the door to Satan's domination over the human spirits as a result of diminishing religious beliefs and insufficient submissions to Allah SWT [10]. Therefore in the Islamic point of view, a person who succumbed to worldly temptations or narcissistic desires indicates lacking in self control and poor attachment to the spiritual aspects or religious practices and faith.

\section{ANXIETY EFFECT AND TREATMENT}

\section{A. The Effects of Anxiety}

In dealing with the demands of life, anxiety may interferes with daily functioning of an individual by reducing focus in thinking, causing inability to sleep and eat, unstable emotions and fatigue [2]. Psychologically anxious person would feel constant worries, feeling upset and fearful without any real reason to the extent of staring blankly, crying or losing their self-esteem [5]. Person afflicted with anxiety and other related mental health problem may exhibit decreased perception of their own self-worth [11]. This can lead to another serious psychological disturbance which is depression [12]. Depression is serious psychological disturbances that have caused millions of suicides cases every year [13].

\section{B. Treatment of Anxiety}

In collective Western perspectives, anxiety is commonly treatable through psychotherapy, pharmacology and sometimes, a combination of both [14]. Drugs such as 
Buspirone, Benzodiazepine and Imipramine to name a few, are meant to calm the patient by acting as antidepressant agent. These drugs however may cause side effects such as constipation and unstable mind [15]-[17]. 'Cognitive Behavioural Therapy' (CBT) is the most commonly used therapy to help patients suffering from anxiety [18] The effectiveness of CBT however has been debated till today because it does produce positive results but patient are not entirely healed [19], [20]. According to Malik Badri [21], patients who undergo western psychotherapy treatment would feel less painful but the depression, anxiety and guilt would remain.

\section{Treatment in Islam}

Muslim scholars and moralists such as Miskawayh (1030 AD), Al-Tusi (1274 AD) and Al-Ghazali (1111 AD) had long acknowledged that health is about maintaining balance between the human body and the human soul. If the soul is weak, it needed treatment and attention just like the physical body and thus therapy and counselling type of treatment are required [22]. Al-Razi (925 AD) in his book 'El-Mansuri' and "Al-Tibb Al-Ruhani' suggested that a physician or medical practitioner must be knowledgeable in matters pertaining to mental and body health in achieving total well being and complete health for the patient during treatment [23]. Ibnu Sina in his book 'As-Syifa' had strongly emphasized about the importance of cleanliness and the purification of the soul which is the key to happiness. By working towards purification of one's soul, all mental diseases will go away [24].

The Islamic teaching believed that healing can only begin by devoting strong faith in Allah S.W.T. Having strong faith or 'tawakkal' in Allah may have tremendous power that can prevent any psychological disease from invading human mind and soul. When a person has submitted his or her self to Allah, the person would gain Allah's blessing and peace of mind and soul can be achieved [25]. 'Solat' or prayer is also an effective known way to treat anxiety. By performing 'solat' it will purify the heart and calming the soul. It also teaches discipline and patience [26]. 'Solat' also is believed to be able to generate the feeling of compassion, spirituality and God consciousness [27]. 'Solat' also can cure anxiety because it promotes endurance, contentment and perseverance that will be useful when the person facing difficulty in life [28].

Beside solat, 'zikir' (chanting the name of Allah) is thought to help clean and protect human heart from the devil. Through zikir, human mind is directed towards remembrance of Allah and towards all positive elements in life; hence anxiety is reduced [29]. Combining 'solat' and 'zikir' will activate the mind and open human hearts reaching for peacefulness. It also strengthens a person's relationship with Allah SWT that in return will release all the fear and anxiety from the person's mind [30].

\section{RELIGIOUS COPING}

Religious ritual such as prayers, meditation and reading sacred text are reported to lower anxiety and depression and reduction in the consequences of stressful life event [31]. The use of spirituality and religiosity practice in the form of adaptive manner can be helpful to individual who have series of psychological distress [32]. Thus, person who utilizes any religious act such as praying or reading sacred text to address the anxiety is known as religious coping [33].

Krauss [34] posited that Islam is a religion that denotes a comprehensive religious way of life. Ad-Din in Islam implies the sanctification of all daily living into worshipful acts that unify life consistent with 'tawahidic' principles (oneness of Allah) of the divine unity. Al-Quran 4: 125.

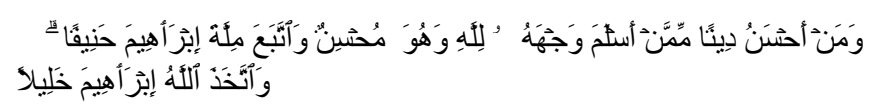

Who is better in religion than he who surrendereth his purpose to Allah while doing good (to men) and followeth the tradition of Abraham, the upright? Allah (Himself) chose Abraham for friend. (125).

The Islamic teaching and practice or Ad-Din should be able to make Muslim maintain this dynamic and moving forward. An ideal Muslim is progressing in their quest of self-purification, self-perspective through worship, ongoing acquisition of knowledge and performing selfless act. Therefore, this study was designed to distinguish the level of anxiety that can be altered or influenced by a person's understanding and application of Islamic teaching and worldview.

\section{METHODS}

\section{A. Sample}

The study was done on two known working sectors, private organization and government offices within Klang Valley. The sampling procedure used was convenient random sampling where a total of 38 participants answered the survey distributed. The questionnaires were collected and analyzed using descriptive and inferential measure. Criterion for enrolment was being a working professional Muslim.

\section{B. Instruments}

The participants had to respond to two set of inventories. The first survey used was 'Brief religious Coping' (BRCOPE) by Pargament [35]. The BRCOPE objective was to gauge the religious coping used by respondents in managing anxiety.

The second instrument used was 'Depression Anxiety and Stress Scale' (DASS) by Lovibond \& Lovibond [36] meant to measure the severity of depression, anxiety and stress that respondents have experienced in the past weeks. For this study, only anxiety will be given attention to. The BRCOPE emphasizes on sample's coping behavior during anxious situations. The response showed will indicate the type of coping behaviors that are frequently used or most effectively used in managing anxiety. Using BRCOPE alone is not sufficient in measuring the severity of the anxiety level. Thus, DASS is used to determine the level of anxiety experienced with the coping behavior used by the study sample.

\section{RESULTS}

A total of 38 respondents have participated in the study. 
Male respondent were 17 (44.7\%), while female participants were $21(55.3 \%)$. The respondents were further distinguished by their working sectors being from the government sector comprises of 20 respondents $(52.6 \%)$, private sectors with 11 participants $(28.6 \%), 3$ respondents from NGO $(10.5 \%)$, and the rest were 4 respondents who were either self-employed or on free-lance terms $(10.5 \%)$.

The mean score for BRCOPE indicated male respondents $t$ (3.03) $p<0.001$, applied more religious coping than female $\mathrm{t}$ (2.89) $p<0.001$. This finding was different from several previous researches where female participants were reported to have higher religious coping score [4]. However, this coincided with the mean score for anxiety for male respondents $t(0.764) \quad p<.001$ which is slightly higher than mean score for anxiety from female respondents $t(0.700)$. This result is different with previous studies where female were reported to have higher anxiety levels compare to male and higher religious coping applications [4], [5], [37].

Mean score for anxiety from working sector showed that government officers had higher score t $(0.821) p<0.001$ while private sector had lower anxiety mean score of $t(0.506)$ $p<0.001$. This result, again coincided with mean RCOPE mean score which were also higher $\mathrm{t}$ (3.07) $p<0.001$ while private sector had lower mean score of $\mathrm{t}(2.74) p<0.001$. It is however a relieving information where all of the respondents' anxiety level falls in normal category only.

Pearson correlation indicates that there exists negative relationship between religious coping and anxiety level. The correlation point at $r=-0.154(p<0.001)$ is considered low compared to the mean score obtained by both Muslim professionals $t(0.821$, government sector) and $t(0.506$, private sectors) in both genders (male 0.764 , female 0.700 ). This indicated that the higher the religious coping used by respondents, the lower the anxiety level they are experiencing.

\section{LIMITATIONS}

The study however has several limitations. The first one is the sample size of the study need to be widened to a bigger number. Working sectors should also be broaden not only from the two main sectors discussed earlier but other sectors such as NGO, self employed and academic or services. The findings obtained from the study also may only represent the two sectors and gender in Klang Valley. The results in this study may be different if the study includes all the different regions in Malaysia.

The study also gathered its data using one method only which is survey method. Future researcher may need to combine with interview and observation as to gain more in depth and thorough understanding about the concept and application of god consciousness and religious coping among Muslim people in Malaysia and maybe other Muslim countries as well.

\section{DISCUSSION AND SUGGESTIONS}

Government officer were reported to have higher anxiety because their fear of being taken action by immediate superior. They applied religious coping also as a result of complying with the code of conduct of the ministry [38]. The security of job, post and ranking were crucial in government's officer's thought. The ideas of being transferred, demoted or fired were barely acceptable and it can affect a person's dignity throughout their service (The 12 Pillars, Institute of Malaysian National Governance (INTAN) [39].

The private sector had being aware and learned to adapt to the uncertainties and challenges. Thus, they will use their skills to survive the corporate world. They have low religious coping practice because they behaviour in and outside work setting were not bound under formal code of practice as the government officers. Changing and quitting from job is another way of climbing the corporate ladder in private sector. In government, seniority is more important in determining one's fate.

Thus, from this study alone it can be said that there exists negative relationship between anxiety levels with religious coping. The result indicated that the higher the religious coping the lower the anxiety level experienced. This showed that religious coping have major influence on respondents' anxiety level. New finding suggested that male respondents were having higher anxiety levels compared to female. The higher anxiety levels experienced by government officer compared to the non-government professionals also indicated the uniqueness of the research's result. Therefore, future studies need to investigate this area to explain and elaborate on this factor further more.

\section{Attaining God Consciousness as Religious Coping}

In Islam, god consciousness is known as 'taqwa' from the Arabic word of 'Waqa yaqi, ittaqa yattaqi' which mean to shield and to protect one self. 'Taqwa' is a process where it involves consistency, commitment and responsibility to be fulfilled by a Muslim [40]. Stress and anxiety are viewed by god fearing people as test and opportunity to improve and become better Muslims. 'Taqwa' promotes constance god consciousness and fearing in every Muslim's mind. As a result, Muslim will be careful in guarding their mind, thought, behaviour and tongue from committing the forbidden (haram) and disliked (makruh) behaviour that can weaken and pollute the heart. By having a strong faith and fear of Allah, Muslim will be blessed and protected by God from disease of the heart such as anxiety, stress and depression.

'Taqwa' plays a large role in Islamic morals and ethics because it is truly what makes people ethically aware of their actions in relation to God. 'Taqwa' gives people a reason to do the right thing. The awareness of God's power makes people want to please him, making 'taqwa' a moral and ethical base for their actions. Because of this construct, 'taqwa' is one of the "ideal ethical values" of the religion of Islam [41]. Thus, 'taqwa' is an effective religious coping strategy for Muslim to manage stress and anxiety.

\section{ACKNOWLEDGMENT}

This study is done by LRGS Grant of USIM/LRGS 


\section{(UUM)/FKP/ULUM/34/50112.}

\section{REFERENCES}

[1] R. Boon. (June 2013). Anxiety. [Online]. Available: http://home.jprimus.com.au/boon/AnxietyPTSDetc.html.

[2] D. H. Barlow, Anxiety and Its Disorders: The Nature and Treatment of Anxiety and Panic, $2^{\text {nd }}$ ed., New York: Guilford Press, 2002, pp. 292-327.

[3] Diagnostic and Statistical Manual of Mental Illness (DSM IV), 1994, APA, pp. 218-227.

[4] N. I. Zohra and E. Irshad, "Religiosity and anxiety disorder in Peshawar," Psychology Department, University of Peshawar, 2012.

[5] C. H. Abdullah, H. N. Ismail, N. S. H. Ahmad, and W. S. M. Hissan, "Generalized Anxiety Disorder (GAD) from Islamic and Western perspectives," World Journal of Islamic History and Civilization, vol. 2 , no. 1, pp. 44-52, ISBN 2225-0883@IDOSI Publication, 2012.

[6] M. A. A. Ghazali, Ihya' Ulum Al-Din, Kaherah: Dar Al-Taqwali Al-Turath, 2000

[7] M. H. Shaharom, Islamic Medical Ethics and Psychiatry Issues (Etika perubatan Islam dan isu-isu psikiatri), Translated, Kuala Lumpur, Dewan Bahasa dan Pustaka, 2008.

[8] M. U. Najati, Psychotherapy according to the Quran (Psikoterapi menurut Al-Quran.), Translated by Hj. Abd. Rahman, Selangor: Human Resource Enterprise, 1992.

[9] H. Zakaria, "Stress management: A review from Islamic perspectives," ("Pengurusan stress. Satu tinjauan dari perspektif Islam,") Translated, Presented at the Bengkel Pengurusan Stress Menurut Perspektif Islam, Kuala Lumpur, 27-28 July, 2004.

[10] A. Taha, Islamic Medical Practices (Kedoktoran Islam), Translated by Ismail Ibrahim, Kuala Lumpur, Dewan Bahasa dan Pustaka, 1992.

[11] T. Pyszczynski and P. Kesebir, "Anxiety buffer disruption theory: A terror management account of posttraumatic stress disorder," Invited article, Anxiety, Stress \& Coping, vol. 24, no. 1, pp. 3-26, January 2011.

[12] K. Amrai, H. A. Zalani, F. S. Arfai, and M. S. Sharifian, "The relationship between religious orientation and anxiety and depression students," Procedia Social and Behavioral Sciences, vol. 15, pp. 613-616, 2011.

[13] G. H. Koenig, E. M. Mccullogh, and B. D. Larson, Handbook of Religion and Mental Health, Oxford University, pp. 1118-20, 2001.

[14] D. H. Barlow and C. L. Lehman, "Advances in the psychosocial treatment of anxiety disorders. Implications for national health care," Archives of General Psychiatry, vol. 53, pp. 727-735, 1996.

[15] J. P. Feighner and W. F. Boyer, "Serotonim-1A anxiolytics: An overview," Psychopathology, vol. 22, pp. 21-26, 1989.

[16] K. Rickels, K. Weisman, N. Norstad, M. Singer, D. Stoltz, A. Brown, and J. Danton. "Buspirone and diazepam in anxiety: A controlled study," Journal of Clinical Psychiatry, vol. 43, pp. 81-86, 1982.

[17] E. Thackery, (Ed.), The Gale Encyclopedia of Mental Disorders, the Gale Group, Inc. 2003.

[18] T. D. Borkovec, M. G. Newman, and L. G. Castonguay, "Cognitive-behavioral therapy disorder with integration from interpersonal and experiential therapies," The Journal of Life Long Learning in Psychiatry, vol. 11, no. 3, pp. 393, 2004.

[19] R. C. Durham, "Treatment of general anxiety disorder," Psychiatry, vol. 6, no. 5, pp. 183-187, 2007.

[20] L. Kase and D. R Ledley, Anxiety Disorders: The Wiley Concise Guides to Mental Health, America, John Wiley and Sons, Inc., pp. 31-31, 2007.

[21] M. Badri. "Successes with Islamic counseling and psychotherapy," Presented at the National Seminar on Islamic Counselling, Kuala Lumpur. Islamic Center of Malaysia, 1995.

[22] M. N. Omar, "Teknik merawat penyakit kemurungan dalam teori kaunseling Al-Kindi," (translated: Techniques in treating depression according to Al-Kindi Counselling Theory), (M874), Presented at the International Seminar on Islamic thoughts proceeding, Kuala Lumpur, International Islamic University, 7-9 December, 2004.

[23] Z. Kamal. Menuju kesempurnaan akhlak, (Translated: Towards attitude perfection by Helmi Hidayah), Bandung: Mizan, 1999.

[24] S. Khalili, S. Murken, A. Helmut, A. Shah, and A. Vahabzadeh, "Religious and mental health in cultural perspective: Observations and reflections after the first international congress on religion and mental health," The International Journal of Psychology of Religion, vol. 12, no. 4, pp. 217-237, 2002.

[25] M. U. Najati, Al-Quran wa ilm Al-Nafs, Qahirah: Dar Al-Shuruq, 1985.
[26] Z. B. Taha, "The Quranic technique of cognitive behaviour," in Abhath Nadwah Ilm Al-Nafs, Cairo International Institute of Islamic Thought, 1993.

[27] Y. Emerick, What Islam is About, Kuala Lumpur, A. S. Nordeen, 2004.

[28] F. Rahman, Islam Ideology and the Way of Life, Singapore: Pustaka Nasional Pte. Ltd, 1980.

[29] M. A. A. Ghazali, "Quwaid Al-Aqaid fi Al-Tawhid," in majmu'ah Rasail Al-Imam Al-Ghazali., Beirut: Dar Al-Kutub, 1994.

[30] T. M. H. A. Shissieqy, A Guide to Zikr and Duas (Pedoman zikir dan doa), Translated, Malaysia: Thinker's library Sdn Bhd, 1983.

[31] D. R. William, D. B. Larson, R. E. Buckler, R. C. Heckmann, and C. M. Pyle, "Religion and psychological distress in a community sample," Social Sciences and Medicine, vol. 32, pp. 1257-1262, 1991.

[32] D. H. Rosmarin, K. I. Pargament, and H. B. Robb, "Spiritual and religious issues in behavior change," Cognitive and Behavioral Practice, vol. 17, pp. 343-347, 2010.

[33] K. I. Pargament, "God help me: Toward a theoretical framework of coping for the psychology of religion," Research in the Social Scientific Study of Religion, vol. 2, pp. 195-224, 1990.

[34] S. E. Krauss, A. Hamzah, R. Juhari, and J. Abd Hamid. "The Muslim religiosity-personality inventory (MRPI): Towards understanding differences in Islamic religiosity among Muslim youth," Pertanika Journal of Social Sciences and Humanity, vol. 13, no. 2, pp. 173-186, 2005.

[35] K. I. Pargament, The Psychology of Religion and Coping: Theory, Research, Practice, New York: Guilford, 1997.

[36] S. H. Lovibond and P. F. Lovibond, Manual for the Depression, Anxiety, Stress Scale, Sydney: Psychology Foundation, 1995.

[37] G. Mahmoudi, A. G. Ebadi, and H. Akbarzadeh, "Religious coping and anxiety in students of Islamic Azad University-Sari Branch, 1999-2000," World Applied Sciences Journal, vol. 2, no. 4, pp. 363-367, ISSN 1818-4952 @IDOSI Pub, 2007.

[38] S. H. S. I. A. Qudsy, A. A. Rahman, and M. I. M. Zaini, "Value and professionalism strengthening towards effective governance in Malaysia," ("Pengukuhan nilai dan profesionalisme di kalangan penjawat awam kearah efektif governan di Malaysia,") Translated, Journal Syariah, Jilid 17, bil., vol. 3, pp. 579-592, 2009.

[39] The 12 Pillars (Tunggak 12), The Ethics Guide for Civil Servants, Institut Tadbiran Awam Negara (C) INTAN, (2 ${ }^{\text {nd }}$ ed.) ISBN 967-9933-15-6, 1993.

[40] Taqwa-The Concept of God-Consciousness in Islam. (2010). Khutbah transcript [Online].

Available: http://malaysia.search.yahoo.com/search

[41] F. Rahman, "Some key ethical concepts of the Qur'an," The Journal of Religious Ethics, pp. 170-85, 2001

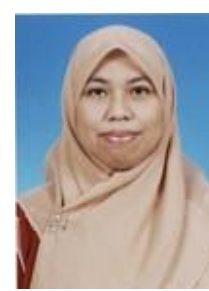

Husni Mohd Radzi is a postgraduate student from Universiti Sains Islam Malaysia (USIM) Selangor , Malaysia. In 2011, she was awarded with M.Ed in Guidance and Counseling from University Putra, Malaysia. She is currently pursuing her $\mathrm{PhD}$ in Counseling in Universiti Sains Islam Malaysia, Negeri Sembilan Malaysia. She had several years experienced as student counselor and teaches counseling and psychology for undergraduates in Universiti Tenaga Nasional, Selangor, Malaysia.

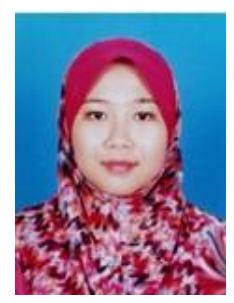

Lilie Zahara Ramly is a fulltime lecturer currently on secondment basis at the International Office as International Liaison Coordinator in UNITEN. She was conferred Master of Education (TESL), from Universiti Putra Malaysia in 2010. She has several years' experience teaching in various education backgrounds. A certified 'Train of Trainers' instructor and has consulted students from all walks of life, conduct professional development courses for multinational companies such as TNB and Sime Darby for professional training in language, communication, management and soft-skills. Besides being an academician and researcher, she also manages student mobility programmes, as well as students' academic, co-curriculum, motivational programmes as well as social community projects. 


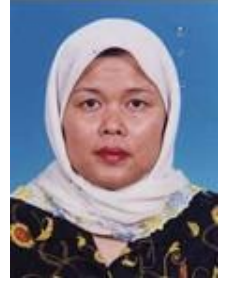

Sapora Sipon is a senior lecturer in USIM. She is an active columnist in a local newspaper and participating in numerous research, paper presentation and conferences locally and internationally. She has published several books related to her field of counseling and psychology. She has won several innovation and invention awards in her years with USIM. She is currently the project leader for this research grant under Ministry of Education.

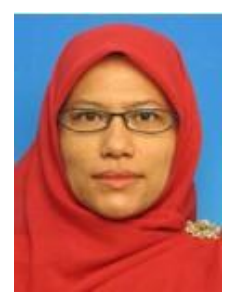

Khatijah Othman is a senior lecturer from USIM. Before she joined academic world, she has a vast experienced as a professional in finance industries. She has published several books and numerous academics papers related to her field of Islamic finance and management which she has presented in both international and local arena. She is also actively involved in several researches under Ministry of Education. 